\title{
Did the EBA Capital Exercise Cause a Credit Crunch in the Euro Area?*
}

\author{
Jean-Stéphane Mésonnier ${ }^{\dagger}$ and Allen Monks ${ }^{\ddagger}$
}

First draft: 28 February 2014.

\begin{abstract}
We exploit a unique monthly dataset of bank balance sheets to document the lending behaviour of euro area banks that were subject to the EBA's 2011/12 Capital Exercise. This exercise was announced in October 2011 and required large European banking groups to meet a higher Tier 1 capital ratio by June 2012, after accounting for an unprecedented temporary buffer against exposure to sovereign debt. Given the unexpected nature of the EBA Exercise and the short time frame during which banks had to increase their capital buffers, this episode comes close to a natural experiment and provides a valuable insight into the capital-lending relationship. Controlling for bank characteristics and demand at the level of country of residence, we find that banks in a banking group that had to increase its capital by 1 percent of risk-weighted assets tended to have annualized loan growth (over the 9 month period of the exercise) that was 1.1 percent lower than for banks in groups that did not have to increase their capital ratio. We find, however, that the timing of this effect is limited to the recapitalisation period. We also look at aggregate effects at the country level and find that banks that did not have to recapitalize did not substitute for more constrained lenders. Our results are of particular relevance for the decisions facing the new European Single Supervisor in advance of its Asset Quality Review due in November 2014.
\end{abstract}

JEL Classification: C21, E51, G21, G28.

Keywords: bank capital ratios, credit supply, EBA, euro area, asset quality review.

\footnotetext{
${ }^{*}$ We thank Marcello Bofondi, Guillaume Horny, Fabio Panetta and John Thanassoulis for useful comments, as well as seminar participants at Banca d'Italia and Banque de France. Aurélie Touchais provided very helpful assistance with the data. The views expressed herein are those of the authors and do not necessarily reflect those of the Banque de France, the Central Bank of Ireland or the Eurosystem.

${ }^{\dagger}$ Banque de France, Financial Research Division, 41-1391 RECFIN, 39 rue Croix des Petits-Champs, 75001 Paris, France. Email: jean-stephane.mesonnier@banque-france.fr.

${ }^{\ddagger}$ Central Bank of Ireland and Banque de France. Allen Monks is on secondment from the Central Bank of Ireland at the Banque de France, Financial Research Division. Email: allen.monks.external@banquefrance.fr.
} 


\section{Introduction}

In October 2011 the European Banking Authority (EBA), the institution charged with setting harmonized supervisory standards for banks in EU Member States, announced that major European banking groups would have to increase their Core Tier 1 capital ratios to $9 \%$ of their risk-weighted assets (RWA) by June 2012. These groups were also required to hold a new temporary capital buffer to cover risks linked to sovereign bond holdings. The announcement came at a time when the euro area was still perceived as extremely fragile, following a tumultuous summer on the sovereign debt markets of several Member States. At the same time, many observers were concerned that impaired bank balance sheets were leading to weak credit supply and aggravating the recession in several European countries. Unsurprisingly, the timing of the EBA's Capital Exercise therefore soon came under fire from critics for having contributed to a "credit crunch" in the euro area. ${ }^{1}$

In this paper, we evaluate the impact of this unexpected increase in regulatory capital requirements on bank lending to the real economy in the euro area. We do this using information released by the EBA on measured capital shortfalls for some 70 banking groups in addition to a novel dataset compiled by the Eurosystem of monthly balance sheets for some 240 large individual banks resident in the euro area (the IBSI database in the following). Controlling for bank characteristics and demand at the level of country of residence, we find that banks in a banking group that had to increase its capital by 1 percent of risk-weighted assets tended to have annualized loan growth (over the 9 month period of the exercise) that was 1.1 percent lower than for banks that were in groups that did not have to increase their capital ratios. Moreover, looking at the variation of banks' CDS spreads around EBA announcements, we provide evidence that this credit contraction indeed reflects forced balance sheet adjustment and not tighter funding conditions due to information revelation about the credit worthiness of banking groups monitored by the EBA. We also look at the timing of the effects and find that the difference in behaviour between banks in shortfall and surplus groups was contained to the 9-month recapitalisation period. This suggested that this instance of an increase in regulatory capital requirement had no persistent effect on lending behaviour. Finally, we collapse our dataset at the country level in order to assess aggregate

\footnotetext{
${ }^{1}$ A prominent example of such criticism is a statement by ECB President Mario Draghi in response to questions by journalists on January 12, 2012: "I think there are usually, by and large, three reasons why banks may not lend. (...) The second reason is a lack of capital. (...) So your question is about the second, a lack of capital. Now, the EBA exercise was in a sense right in itself, but it was decided at a time when things were very different from what they are today. (...) So in itself under these circumstances the EBA exercise has turned out to be pro-cyclical."
} 
effects and find that banks that were not constrained to recapitalize did not substitute for those that had to increase their capital ratios. This suggests that the Capital Exercise had procyclical macroeconomic effects of similar orders of magnitude.

Capital requirements have been the cornerstone of modern banking regulation since the late 1980s. Since then, proposals for increasing requirements have been contentious, with the financial industry generally claiming that higher requirements would force them to substantially reduce lending to the real economy, at least temporarily. ${ }^{2}$ According to this line of argument, the costs of higher requirement could therefore outweigh the potential financial stability benefits, which are generally put forward by regulators. In spite of an abundant empirical literature over the course of more than two decades, the magnitude (if not the sign) of the short term response of loan supply to a shock increasing bank capital requirements remains a much debated issue. ${ }^{3}$

Any attempt to evaluate the impact of a capital requirement shock on lending supply faces several challenges. First, new regulations, such as Basel I to III, have generally been announced well ahead of their implementation explicitly in order to allow banks to smoothly adjust their balance sheets. This makes the task of identifying an unexpected shock to capital requirements and measuring the short-term impact on loan supply quite difficult. ${ }^{4}$ Second, as with the 2007-2009 subprime crisis, regulators may increase requirements on account of weakness in credit demand or a deterioration in the credit quality of borrowers. Similarly to the difficulty of measuring the impact of a bank capital shock more generally, disentangling demand and supply effects is therefore not straightforward. Third, changes to bank regulations tend to affect all large banks of a given country at the same time, making it difficult to construct appropriate control groups of untreated but similar institutions.

The characteristics of the EBA's exercise and of our dataset allow us to address these challenges in a rather satisfying way. First, a remarkable feature of the EBA Capital Exercise was that it was largely unexpected, with the EBA announcing its exercise just a few months after having drawn relatively benign conclusions from its own June 2011 stress tests. This surprise effect limits the odds that banks could have preemptively adjusted their

\footnotetext{
${ }^{2}$ See IIF (2010), a think-tank representing of large international banks, for an alarming view of the possible consequences of the Basel III capital package on credit supply and growth, and Admati et al. (2011) for a critical survey of the fallacies often associated with the claim that raising capital requirements would be detrimental to lending to the real economy.

${ }^{3}$ See for instance Hanson, Kashyap and Stein (2010) for a recent and rather consensual survey of the empirical evidence on the short-run capital-lending relationship.

${ }^{4}$ For example, while Furfine (2000) claims that higher capital ratios (or the tougher associated monitoring by supervisors) were responsible for slower lending growth in the 1990s in the US, Berger and Udell (1994) tend to dismiss the role of Basel regulations in this slowdown.
} 
balance sheets, which would bias downward the estimated effect on lending. Furthermore, the level of the new required Core Tier 1-to-RWA ratio was substantially higher than that planned under the transition to Basel III and explicitly not related to the level of risks of any particular banking group, but rather to insure that all large European banks accumulated sufficient capital cushions to withstand a further deterioration in the sovereign debt crisis. The horizon set by the EBA to meet the higher requirement (about eight months) was also remarkably short compared to, for example, the pace of the Basel process, making it more plausible in a difference-in-difference setting like ours that the observed change in lending over the period was a consequence of the capital requirement shock. All of these elements mean the Capital Exercise comes close to a natural experiment and provides us with a rare opportunity to observe an exogenous regulatory shock on bank capital.

Second, an attractive feature of our dataset is that while we observe the capital shock at the banking group level, we measure the response of credit at the level of individual bank, which may be located in different euro area countries. For the non-financial sector of a given country, we can therefore compare the change in credit received from resident banks belonging to the same group and from resident banks belonging to different groups facing different EBA requirements and, possibly, headquartered in different countries. This disaggregated information about banking groups, as well as the multinational nature of the Capital Exercise and the presence of foreign subsidiaries of European banking groups in our sample, allows us to improve upon the type of controls for credit demand typically used in similar studies. Indeed, our results are robust to the inclusion of alternative measures of country-specific effects, including country dummies, suggesting that we correctly control for demand at the country-of-residence level.

Third, the design of both the EBA sample of European banking groups and of the IBSI sample of euro area banks allows us the possibility of constructing a representative sample of euro area lending institutions and of designing credible control groups for a difference-in-difference analysis. Indeed, while the EBA dataset has a wide coverage of large European banking groups, including all the European G-SIFIs, the IBSI dataset includes many individual banks of similar size, which may or may not belong to groups monitored by the EBA. In order to improve the accuracy of our estimates, we choose as our baseline sample a large sample including both IBSI banks belonging to EBA groups and IBSI banks belonging to groups not subject to the EBA exercise. However, we show that belonging to an EBA group does not really matter per se and that our results are robust to limiting the sample to banks that were part of groups subject to the exercise. 
Finally, a nice feature of the IBSI dataset is that we can observe "true" net flows of bank credit instead of approximating them with the changes in credit outstanding at the start and the end of the Capital Exercise, as is typical in comparable studies using bank balance sheet data. These credit flows represent changes in credit stocks corrected for various sources of statistical noise, including write-offs, exchange rate effects, reporting changes and reclassifications. These corrections are basically the same as those implemented by Eurosystem statisticians when computing the growth rates of credit aggregates at the country level. The IBSI dataset also includes detailed meta-information about mergers and acquisitions, sales and buy-backs of securitized loans. We can therefore explicitly control for such events when constructing our measure of bank loan growth. We are thus able to construct quite clean measures of bank-level credit growth to the non-financial sector.

From a policy perspective, we view our findings as providing a useful benchmark for the new European Single Supervisor, as the decisions it will have to take when completing the Comprehensive Assessment (launched in October 2013) may include higher capital requirements and new regulatory capital weights imposed on sovereign debt holdings. ${ }^{5}$ Indeed, our study is the first to provide an assessment of the effect on bank credit of a well-identified regulatory capital shock at the euro area level. Clearly, our results best illustrate the likely consequences of a regulatory tightening in the short run (the horizon of the measured effect in this study is 9 months) and, importantly, of a tightening implemented in a period of financial market stress. Indeed, the sovereign debt crisis was raging in late 2011, with many concerns related to possible feedback loops between banks' and sovereigns' credit quality. Our findings could therefore represent an upper bound of the expected macroeconomic effects of such a shock, as in more normal times healthier banks would presumably be better able to substitute for the reduction in credit supplied by capital-constrained banks. ${ }^{6}$ At the same time, the magnitude of our estimated effect lies at the lower range of estimates available from comparable recent studies, which we survey below. There are two period-specific factors that may have contributed to dampening the consequences of the capital shock arising from the EBA's exercise. First, in early December 2011, the Eurosystem launched its three-year Long Term Refinancing Operations (LTROs), thus injecting in two waves (in

\footnotetext{
${ }^{5}$ Cf. interview of Danièle Nouy, Head of the SSM, with the Financial Times of February 10, 2014 (available at: http://www.ecb.europa.eu/press/inter/date/2014/html/sp140210.en.html).

${ }^{6}$ Although, at least in the short run, asymmetries of information only alleviated by relationship lending could limit such substitution. Cf. Bernanke (1983) for his seminal study of the impact of destroyed relationship lending on the severity of the US Depression, and Gambacorta et al. (2012) for a recent study showing that relationship lending helped shield Italian firms from the effects of the 2007-2008 liquidity freeze on wholesale funding markets tapped by their Italian banks.
} 
late December 2011 and early March 2012) some one trillion euros at very favorable rates into the euro area banking system. Although the amounts borrowed by each bank was not public information, this move led to a general loosening of funding conditions on financial markets (as measured for instance by the CDS spreads and equity returns of major banks), thus possibly improving the ability of banking groups to raise new equity. We have no way of controlling for this contrarian LTRO effect, however, as the Capital Exercise covered banking groups in the whole EU, whereas our dataset of individual bank balance sheets is limited to euro area banks. Second, the EBA explicitly called for an adjustment of capital ratios with minimal resort to deleveraging and discussions with regulators, in particular in some stressed countries, lead us to conclude that national supervisors exerted moral suasion upon the managers of major domestic banks in order to minimize the impact of the required adjustment on lending to the real economy.

The rest of the paper is organized as follows. Section 2 reviews some of the relevant literature on the relationship between bank capital shocks and credit supply. Section 3 summarizes the timeline and the requirements of the EBA Capital Exercise. We provide details on our dataset and our methodology in Section 4. Section 5 presents the results of our baseline regression at the bank level and provides evidence that the estimated impact of the Exercise on credit provision is not related to information revelation by the EBA, which confirms our story. In Section 6, we outline a series of robustness tests that we undertake on our baseline results. Finally, Section 7 looks at the timing of the effect, Section 8 presents results of our analysis on country aggregates and Section 9 concludes.

\section{Literature Review}

The theoretical literature on the relationship between bank capital and credit supply suggests that banks will respond to a shock that increases their capital constraint by reducing credit supply. In the long run, the consensus view is that the Modigliani and Miller (1958) theorem should apply and ensure that the quantity of loans granted by banks is largely disconnected from their capital structure. However, as far as short run adjustments are concerned, notably in crisis times, a series of standard arguments based on informational frictions in the market for bank equity point to reasons why issuing more equity capital can be costly for banks, thus departing from the Modigliani and Miller world. ${ }^{7}$ Faced with

\footnotetext{
${ }^{7}$ The pecking order theory (Myers and Majluf, 1984) points to an adverse selection problem due to the opacity of banks' assets. Issuing equity could thus send the signal that the bank is in distress, which would prompt investors to require a lower price for buying new shares, thus diluting existing shareholders. Moreover, highly leveraged banks may face a debt overhang problem (Myers, 1977), preventing new shareholders
} 
difficulty in raising new equity to meet their capital requirements (be they imposed by investors or by regulators), banks are incentivized to deleverage their balance sheet or, if the binding constraint is expressed in proportion to risk-weighted assets, to shift their assets from investments with a higher capital weight (like corporate loans) to investments with a lower one (like, under current Basel rules, government bonds of developed economies). ${ }^{8}$

Since the early 1990s, and following the inception of the first comprehensive regulatory package on capital requirements for large international banks set up by the Basel Committee, the role of tightened capital regulations in aggravating recessionary episodes has been widely discussed. Early empirical studies, like Bernanke and Lown (1991), assess the impact of bank capital constraints on lending during a recessionary episode by regressing loan growth on the pre-crisis level of each bank's capital. They confirm that less capitalized banks tend to lend less after a shock that is likely to have made the regulatory constraint more binding. However, they reject the hypothesis of a widespread credit crunch during the 1990-1991 recession in the US. In a similar vein, Peek and Rosengreen (1997) use the Japanese crisis as a natural experiment and regress lending by branches of Japanese banks in the US on the capital ratio of their parent institutions, which is arguably exogenous to the level of economic activity in individual US states. With this neat empirical setup, they find that a 1 percentage point decline in lending by the parent's capital leads to a reduction in the US branch by 6 percent.

A second set of studies postulate that banks adjust their lending to changes in a capital buffer, defined as the gap between their actual and desired capital ratios, instead of reacting to changes in the capital ratio per se. In such a framework, the desired capital ratio is generally assumed to reflect both regulatory demands and investors' concerns about the bank's solvency. Changes in this target ratio do not, therefore, necessarily reflect changes to regulatory capital requirements alone. Assuming that the desired ratio relates in a simple (linear) way to banks' characteristics and the macro outlook and that banks can only adjust gradually their capital ratio to their desired level, this target ratio is easily filtered out from observed capital ratios. Following Hancock and Wilcox (1994), several recent papers implement such a partial adjustment model on a panel of banks, as Berrospide and Edge (2010) do for the US, Maurin and Toivanen (2012) for the euro area and Francis and Osborne (2009) for the UK. The latter find, for instance, that a one percentage point increase in UK banks' capital requirements in 2002 would have reduced their lending by $1.2 \%$ on average

to step in as all future profits are likely to be absorbed by incumbent debt-holders.

${ }^{8}$ Cf. for instance Thakor (1996). 
after four years, a magnitude that compares well with our findings.

A shortcoming of studies based on partial adjustment models of bank capital to an unobservable target ratio is that the results are strongly dependent on the assumptions underlying the measure of the target ratio. Another limitation relates to the granularity of the information used, as most papers using such models run panel regressions of loans on capital at the bank level for a given country, which limits the possibility to adequately control for changes in credit demand. ${ }^{9}$ Other strands in the empirical literature thus explore such avenues as using different measures of the capital constraint, using more disaggregated data (like loan-level information), or exploiting bank-specific regulatory changes in countries where this information is available (such as in UK).

As an example of the first strand of papers, Basset and Covas (2012) assess the capital constraint faced by US banks by using banks' own assessment of their capital adequacy, as revealed in their responses to the Fed's Senior Loan Officer Opinion Survey (SLOOS). After correcting for some classification errors, they find that a one-standard-deviation increase in the probability that a bank tightened standards because it was concerned about its capital translates into a 1.3 to 1.7 percentage point reduction in the annualized growth rate of loans over the subsequent quarter relative to a bank that also tightened standards but did not become more capital constrained.

Second, since the seminal contributions of Khwaja and Mian (2008) and Paravisini (2008), a number of recent papers have explored anew longstanding issues in empirical banking using very disaggregated information, either at the loan level or at the level of the exposure of individual banks to individual firms, as recorded in the credit registers of some countries. Including firm and time fixed effects in panel regressions run at the level of firm-bank credit exposures indeed allows for a very convincing control of credit demand effects when enough firms have multiple banks. In this vein, Puri et al. (2011) provide evidence that German Landesbanken that were exposed to the US subprime markets (and thus suffered a sharp capital depletion over 2007-2008) did ration credit to retail borrowers. Albertazzi and Marchetti (2010) look at the change in credit supplied by Italian banks to local firms over the six months of turmoil that followed the Lehman collapse. They find evidence of a contraction of credit supply, associated with low bank capitalization. Furthermore, among less-capitalized banks, they find that larger banks reallocated loans away from riskier firms, thus contributing to credit procyclicality.

\footnotetext{
${ }^{9}$ Implicitly, all banks are supposed to face the same intensity of demand, as summarized by, for example, measures of the country's business cycle
} 
Finally, a series of studies take advantage of proprietary datasets on bank-specific changes to capital requirements imposed by supervisors, allowing for a better identification of the capital regulation tightening shock. Aiyar et al. (2012) and Bridges et al. (2014) exploit the time-varying minimum capital requirements (so-called 'trigger ratios') imposed by the Bank of England (formerly the FSA) at the level of individual banks in the 1990s and 2000s. In both cases, they control for demand using information about the industrial sector of the borrowers. Aiyar et al. (2012) find that a rise of one percentage point in the trigger ratio induces a cumulative reduction in the growth rate of bank lending of between 6 and 9 percentage points. Bridges et al. (2014), who also use "clean" measures of credit flows instead of changes in stocks, find that banks respond to increases in capital requirements in the first year by restricting credit supply (notably with respect to secured lending to households and non-real estate loans to firms) and growing their capital base. Thereafter, banks increase their capital resources until they have restored the capital buffers (above regulatory requirements) they were holding before the increase in capital requirements and, therefore, stop constraining lending supply after the first year. Their estimates point to a reduction in loan growth in the first quarter of 2 percentage points for corporate loans following a increase in trigger ratios by 1 percentage point. Last, a recent paper of Brun et al. (2013) exploits French loan level data and detailed supervisory information about banks' internal model choices in their transition from Basel I to Basel II, which directly impacts on the tightness of the capital constraint they face. Looking at the intensive margins (changes to existing exposures), they find that a 1 percentage point increase in bank-specific capital requirements leads to a reduction in lending by 5 to 10 percent, depending on the precise specification of the dependent variable. These results provide an upper bound to available estimates.

\section{The EBA Capital Exercise}

\subsection{Overview}

The EBA announced its capital exercise (referred to hereafter as the Capital Exercise) on 26 October 2011, requiring banks to "strengthen their capital positions by building up a temporary capital buffer against sovereign debt exposures" and to raise their Core Tier 1 capital ratio to $9 \%$ "after accounting for [this] additional buffer against sovereign risk holdings" ${ }^{10}$ These targets were to be met by June 2012. The exercise was undertaken with

\footnotetext{
${ }^{10}$ A bank's capital shortfall/surplus was calculated using the following formula:

Shortfall $_{\text {Sept } 2011}=\left(0.09 \times R W A_{\text {Sept } 2011}-\right.$ CoreTier $\left._{1_{\text {Sept } 2011}}\right)+\left(\right.$ SovereignBuffer $\left._{\text {Sept } 2011}\right)$
} 
the aim of building confidence in the ability of euro area banks to withstand credit shocks, including those arising from their holdings of sovereign bonds. It followed the July 2011 EUwide stress tests, which had recommended capital strengthening for banks with a Core Tier 1 ratio below $5 \%$ and for those with significant holdings of stressed sovereign debt. ${ }^{11}$ The EBA published an initial country-level estimate of required capital-raising on 26 October 2011. On 8 December 2011, it published a formal Recommendation with bank-level figures based on September 2011 balance sheet data. Twenty seven banks were identified as having an aggregate capital shortfall of $€ 76 \mathrm{bn}$ and were required as a consequence to submit capital plans to the EBA through their national supervisory authorities by 20 January $2012 .{ }^{12}$ The EBA published a preliminary assessment of the plans on 9 February 2012, emphasizing that the measures were not "viewed as having a negative impact on lending into the real economy". On 11 July 2011, the EBA published its preliminary report on the capital exercise, stating that the "vast majority" of banks had met the capital requirement. ${ }^{13}$ The final report, including end-June 2012 detailed balance sheet information for all participating banks, was published on 3 October 2012.

The timing of the capital exercise was criticized by a number of commentators for potentially aggravating a credit crunch in the euro area. However, in its communication, the EBA consistently emphasized the need for banks to address capital shortfalls without constraining credit provision to the real economy. For example, the Recommendation of 8 December 2011 outlined a hierarchy of capital-raising measures, emphasizing the use of liability management and stating that national authorities could only agree to asset disposals if as they did not "lead to a reduced flow of lending to the EU's real economy". Furthermore, the EBA and national authorities were to ensure that capital targets were "not achieved through excessive deleveraging, disrupting lending into the real economy".

Eligible Core Tier 1 capital was defined in a methodological note of 8 December 2011 as the same used in the previous EBA-led stress tests. Capital comprised the highest quality capital instuments (common equity, i.e. ordinary shares or similar instruments), but also some government suppport measures and some types of newly issued contingent convertibles (CoCos), as detailed in the EBA's documentation. The sovereign buffer was calculated by removing prudential filters on sovereign assets in available-for-sale portfolios and by using a conservative valuation of sovereign debt exposures in held-to-maturity and loans and receivables portfolios, whereby banks were required to build a capital buffer against the difference between the book value of these assets and their market value as of 30 September 2011.

${ }^{11}$ The EBA used the same population of banks for the EU-wide stress tests and the Capital Exercise, although some small, non cross-border banks were excluded from the latter.

${ }^{12}$ The capital exercise covered 71 banks, 37 of which showed an aggregate shortfall of $€ 115 \mathrm{bn}$. Three of these banks were not required to submit capital-raising plans as they were undergoing "deep restructuring". Plans were also not requested from 6 Greek banks, which were being recapitalised in the context of an EU-IMF Programme. One bank that submitted a plan subsequently entered intensive restructuring and exited the exercise.

${ }^{13}$ At this time, government backstops were being put into place for 4 of the 27 banks . 
In total, the 27 banks increased their capital by $€ 115.7 \mathrm{bn}$. According to the EBA's final report, $€ 83.2 \mathrm{bn}$ of this related to direct capital measures, while $€ 32.5 \mathrm{bn}$ related to the impact of RWA measures. Contributing to the latter figure was a fall in RWAs of $€ 42.9 \mathrm{bn}$ (0.87\% or total RWAs as at September 2011) arising from reductions in lending. The EBA concluded: "In line with the Recommendation, capital plans have not led directly to a significant reduction of lending into the real economy. A deleveraging process had already started before the capital exercise and will need to continue in an orderly fashion".

Table 1: Timeline of EBA Announcements

26 October 2011 - Announcement of Capital Exercise requiring banks to build up a temporary capital buffer against sovereign exposures and to establish a Core Tier 1 capital ratio of $9 \%$ by June 2012 .

- Publication of estimated country-level capital shortfall based on June 2011 balance sheet data (total shortfall of $€ 106 \mathrm{bn}$ ).

- Final shortfall scheduled to be published in November 2011 based on end-September data.

- Banks initially expected to submit recapitalisation plans by end-2011.

8 December 2011 - Publication of bank-by-bank shortfall: total of $€ 115$ bn for 37 banks. Ten of these banks subsequently exited the exercise.

- Submission of recapitalisation plans by 20 January 2012.

9 February 2012 - Publication of preliminary assessment of banks' capital plans: 27 banks to fill a total shortfall of $€ 76 \mathrm{bn}$.

11 July 2012 - Publication of preliminary report on the implementation of the capital requirements; "vast majority" of banks meet $9 \%$ Core Tier 1 ratio.

3 October 2012 - Publication of final report and end-June balance sheet data. 


\section{Data and methodology}

\subsection{Data Sources}

The data used in our analysis come from three sources. Firstly, we use consolidated banking group balance sheet data published by the EBA as part of its capital exercise. These data, which are available on the EBA's website, are available for three dates: September 2011, December 2011 and June 2012. The data contain the capital shortfall/surplus calculated by the EBA. The Capital Exercise initially covered 71 banking groups but 10 of these exited the exercise before its completion due to restructuring. Using these data, we calculate a ratio of the group's capital shortfall to its risk-weighted assets (Shortfall-to-RWA) as of September 2011. This ratio is truncated at zero for banks with a capital surplus.

Secondly, we use a unique dataset of the monthly balance sheets of individual Monetary Financial Institutions (MFIs) collected by the Eurosystem for the purpose of conducting more in-depth analyses on the transmission mechanism of monetary policy during the sovereign debt crisis. This dataset covers 247 MFIs, or "banks", which were selected from the total population of euro area MFIs in order to create a sample that would be representative of euro area bank lending activity. For example, the sample includes the 150 largest MFIs (by main assets) as well as most of the banks that report to the ECB's Bank Lending Survey. MFIs from all euro area countries are included in the dataset, which consists of monthly stock and flow data for 24 balance sheet items beginning (for the majority of banks) in August 2008. These balance sheet items were selected in order to allow for the analysis of bank lending to the non-financial private sector (firms and households) as well as the funding activity of banks. Credit to the general government sector and bank' holdings of sovereign debt is also covered.

Finally, we use daily CDS prices for all large European banking groups. We consider 5-year maturity modify-to-modify CDS contracts, which are generally viewed as the most standard and liquid contracts. Price series over the period of interest are available for 43 banking groups in the EBA sample. We take this information from Bloomberg and use it to test whether the effect of the Capital Exercise on bank lending can be explained by information revealed about the creditworthiness of European banks at the time of the first EBA releases. 


\subsection{Preparation of Dataset}

The first step of our analysis consists of a mapping of individual banks (IBSI dataset) and banking groups (EBA dataset). This allows us to divide the IBSI dataset into three categories: 1) banks in banking groups identified as having a capital surplus; 2) banks in banking groups identified as having a capital shortfall; and 3) banks that were not part of banking groups included in the Capital Exercise. Using information on banking groups in the IBSI dataset, we are also able to identify whether banks in the third category are standalone banks or members of a group. The IBSI dataset does not, however, allow for a full reconstruction of group-level balance sheets. This leads to the assumption that an identified capital shortfall at the group level has an impact on the lending growth of all entities within the group. Such an assumption implies two hypotheses: 1) bank credit policy is set at the group level; and 2) internal capital markets exist within banking groups. ${ }^{14}$

Table 2: Count of EBA Groups and IBSI Banks

\begin{tabular}{lc}
\hline \hline Banking Groups in Capital Exercise & 61 \\
\hline IBSI Banks & 247 \\
- of which in EBA & 142 \\
- of which not in EBA & 105 \\
\hline Mapped but no EBA data & $(14)$ \\
Mapped but no IBSI data & $(4)$ \\
IBSI with small loan books & $(24)$ \\
Non-resident banks in Luxembourg \& Ireland & $(7)$ \\
\hline Sample of Banks & $\mathbf{1 9 8}$ \\
- of which in EBA & 123 \\
- of which not in EBA & 75 \\
Sample of Bank Groups & $\mathbf{1 1 8}$ \\
-of which in EBA & 51 \\
-of which not in EBA & 67 \\
\hline \hline
\end{tabular}

Of the 247 banks in the IBSI dataset, 14 fall out of the sample as they are part of the 10 groups that exited the EBA exercise. We also exclude 24 banks that had loan books that were less than $5 \%$ of total assets in September 2011, 7 non-resident banks in Luxembourg and Ireland, and 4 banks with omitted data points over the period of the capital exercise. ${ }^{15}$

\footnotetext{
${ }^{14}$ Many empirical studies vindicate the hypothesis that internal capital markets matter, so that the holding company is the appropriate level of observation: Ashcraft (2008), Ehrman and Worms (2004), Houston et al. (1997) to quote a few.

${ }^{15}$ We exclude the following banks resident in Luxembourg: BGL BNP Paribas, ING Luxembourg S.A., Société Générale Bank \& Trust, Deutsche Bank Luxembourg S.A., UniCredit Luxembourg S.A. and DZ Privatbank S.A.. Other non-resident banks in Luxembourg fall out of the sample as their loans-to-assets ratios were less than $5 \%$ in September 2011. We also exclude Depfa Bank AS, which is resident in Ireland.
} 
Following this stage of data cleaning, we are left with a sample of 198 banks (see Table 2)

in 118 banking groups, 51 of which are banking groups subject to the Capital Exercise.

Table 3: Representativeness of Data Sample

\begin{tabular}{rcccc}
\hline \hline Country & Country Percentages & \% Loans in Sample & Banks in Sample & \% of Shortfall Banks \\
\hline AT & $3 \%$ & $38 \%$ & 8 & $50 \%$ \\
BE & $2 \%$ & $77 \%$ & 9 & $22 \%$ \\
CY & $0 \%$ & $55 \%$ & 4 & $50 \%$ \\
DE & $23 \%$ & $49 \%$ & 56 & $29 \%$ \\
EE & $0 \%$ & $92 \%$ & 4 & $0 \%$ \\
ES & $17 \%$ & $67 \%$ & 23 & $30 \%$ \\
FI & $2 \%$ & $48 \%$ & 6 & $0 \%$ \\
FR & $19 \%$ & $68 \%$ & 28 & $54 \%$ \\
GR & $2 \%$ & $0 \%$ & 0 & - \\
IE & $2 \%$ & $73 \%$ & 10 & $0 \%$ \\
IT & $15 \%$ & $53 \%$ & 23 & $35 \%$ \\
LU & $1 \%$ & $18 \%$ & 2 & $0 \%$ \\
MT & $0 \%$ & $82 \%$ & 4 & $0 \%$ \\
NL & $8 \%$ & $90 \%$ & 8 & $25 \%$ \\
PT & $3 \%$ & $70 \%$ & 5 & $100 \%$ \\
SI & $0 \%$ & $58 \%$ & 5 & $67 \%$ \\
SK & $0 \%$ & $55 \%$ & 3 & $33 \%$ \\
\hline \hline
\end{tabular}

Table 3 presents data on the distribution of lending in the euro area, the representativeness of our sample, the number of banks per country, and the proportion of these banks that are part of a banking group with a capital shortfall. These figures show that our sample of 198 banks covers 60 percent of total bank lending in the euro area. Of these 198 banks, 66 $(33 \%)$ are in banking groups that were subject to the Capital Exercise and showed a capital shortfall. While this proportion varies across countries, only 5 small euro area countries (excluding Greece) have no resident banks with a capital shortfall.

We calculate lending growth rates based on stock and adjusted flow data ${ }^{16}$ in the IBSI dataset. The one-month growth rate of loans $\left(I^{1}\right)$ is calculated as per the following formula:

$$
I_{t}^{1}=\frac{F_{t}^{M}}{L_{t-1}}
$$

where $F^{M}$ represents the one month adjusted flow of lending and $L$ represents the outstanding stock of loans.

\footnotetext{
${ }^{16}$ Loan flow data are adjusted for loan reclassifications, exchange rate movements and other revauluations.
} 
We clean these data for the impact of $84 \mathrm{M} \& \mathrm{~A}$ and 9 securitization operations over the full IBSI sample (August 2007 to June 2013) and winsorize the remaining data at the 2nd and 98th percentiles. We then calculate annualized 9-month growth rates using the following formula, based on the methodology described in the ECB's Monthly Bulletin:

$$
I_{t}^{9}=\left[\left(\prod_{i=0}^{8}\left(1+\frac{F_{t-i}^{M}}{L_{t-1-i}}\right)\right)^{\frac{12}{9}}-1\right]
$$

Table 4: Summary Statistics of Banks in Sample (September 2011)

\begin{tabular}{lccccc}
\hline \hline & $\mathrm{N}$ & mean & sd & min & max \\
\hline Main Assets (Millions) & 198 & 84,798 & 131,796 & 549 & 790,315 \\
Annualised Loan Growth (Recap Period) & 198 & 0.01 & 0.08 & -0.20 & 0.28 \\
Loans to Assets & 198 & 0.47 & 0.22 & 0.05 & 0.96 \\
Capital to Assets & 198 & 0.08 & 0.05 & 0.00 & 0.40 \\
Liquid Assets & 198 & 0.22 & 0.17 & 0.00 & 0.89 \\
Deposits to Assets & 198 & 0.35 & 0.24 & 0.00 & 0.98 \\
Interbank Liabilities to Assets & 198 & 0.20 & 0.19 & 0.00 & 1.00 \\
Deposit to Loans & 198 & 0.90 & 1.48 & 0.00 & 15.90 \\
\hline \hline
\end{tabular}

Table 4 presents some summary statistics for the banks in our sample as at September 2011, i.e., immediately prior to the announcement of the Capital Exercise. These figures show that we have a large range of bank sizes in our sample, from $€ 549 \mathrm{mn}$ to $€ 790,315 \mathrm{mn}$. ${ }^{17}$ The average annualized loan growth during the period of the Capital Exercise was quite small, indicating the generally subdued economic environment during this period. The range for this figure is also large, however. The minimum figure of zero for the deposits-toassets ratio indicates that our dataset incorporates non deposit taking institutions. Related to this, the incidence of very high interbank-liabilites-to-assets ratios probably reflects the fact that some banks were highly reliant on Eurosystem liquidity at this time (central bank borrowings are included in the interbank liabilities figure). Finally, it must be noted that the capital variable in the IBSI dataset is very broadly defined and encompasses Tier 1 and Tier 2 capital as well as some additional reserves, which explains why the average capital to assets ratio displayed in Table 4 is much higher than usual measures of raw leverage based on Tier 1 capital.

\footnotetext{
${ }^{17}$ These figures are converted to logs when used in our regression analysis.
} 


\subsection{Methodology}

The aim of our analysis is to test whether banks that were obliged to increase their capital buffers as part of the Capital Exercise (treatment group) exhibited significantly different lending behavior over the recapitalization period (October 2011 to June 2012) compared to banks that were not obliged to increase their capital buffers (control group). ${ }^{18}$ This latter group consists of two categories: 1) banks that were part of groups identified as having a capital surplus; and 2) banks that were not part of groups monitored by the EBA. We therefore undertake our analysis using the full sample described above, i.e., 198 banks.

Our baseline model is as follows:

$$
Y_{i}=\alpha+\beta_{1} \text { Shortfall }_{i}+\beta_{2} X_{i, k}+S_{i}+\epsilon_{i}
$$

where $Y$ is the annualized 9-month growth of total loans for bank i, Shortfall is the ratio of the capital shortfall (in euros) to the bank's risk-weighted assets (equal to zero for banks in our control group), $X$ is a matrix of bank characteristics, $S$ is variable that controls for country-level loan demand, and $\epsilon$ is the residual. We include the variable $S$ in order to account for the possibility of a lower level of loan demand in "stressed" euro area countries during this period. ${ }^{19}$ While it would be more satisfactory to include country fixed effects, this would require the introduction of 16 dummy variables and significantly reduce the degrees of freedom in our regression analysis, which would be problematic given the small size of our sample. The results of our regressions are presented in the next section.

\section{Results}

Figure 1 shows the evolution of the adjusted stock of loans for our control group (surplus and non-EBA banks) and our treated group (shortfall banks), indexed at one in September $2011{ }^{20}$ This graphical analysis shows that the evolution of lending was broadly similar for the two groups prior to the announcement of the Capital Exercise in October 2011. There

\footnotetext{
${ }^{18}$ Although the EBA did not published finalised capital shortfall/surplus figures until 8 December 2011, it is possible that banking groups were able to predict their results at the time of the announcement of the Capital Exercise (26 October 2011) and start adjusting their balance sheet at that time. We therefore set the adjustment period as being equal to the entire length of the Capital Exercise.

${ }^{19}$ We define 7 euro area countries as having been stressed at the time of the Capital Exercise: Cyprus, Greece, Ireland, Italy, Portugal, Slovenia and Spain.

${ }^{20}$ We calculate the adjusted loan stock figures using the actual loan stock at the start of the ISBSI sample (August 2007) and adding on a cumulated monthly flow figure derived from our monthly growth rates. These adjusted stock figures therefore reflect the data cleaning described in Section 4.2 and are consistent with our subsequent regression analysis.
} 


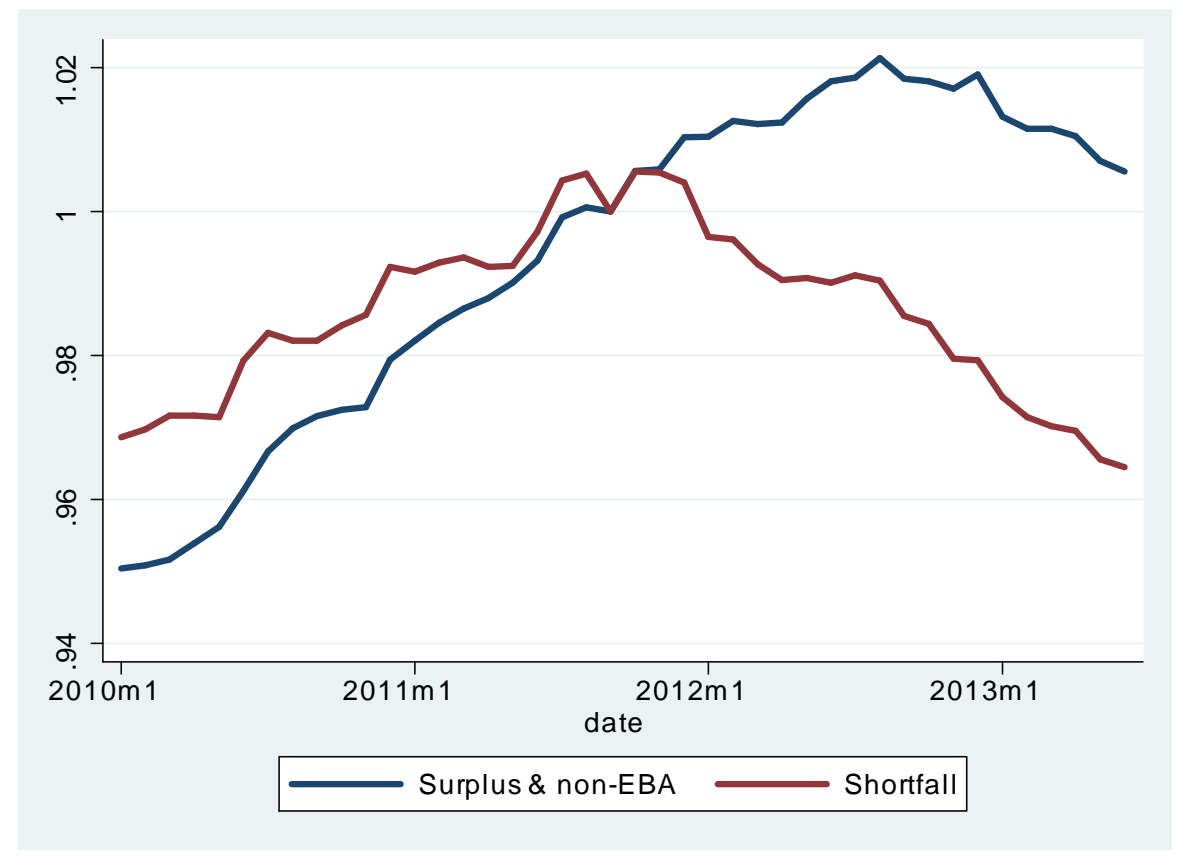

Figure 1: Total loans outstanding (Sept 2011=100): cumulated over control vs. treated groups.

is a sharp divergence following the announcement, however, with banks in the control group continuing to increase their stock of loans during and following the Capital Exercise, while banks in the treated group started to reduce their stock of loans almost immediately after the announcement of the exercise.

This relationship is borne out in regression analysis. Table 5 shows the results from our baseline regressions. Column 1 is a simple regression of annualized loan growth during the Capital Exercise on the Truncated Shortfall-to-RWA ratio. Column 2 and 3 add alternative control measures for credit demand at the country level (i.e. a dummy that takes the value of one for "stressed" (mostly peripheral) EMU countries or the average unemployment rate over the course o the Capital Exercise) taken here as a proxy for the degree of slack in domestic economic activity. Columns 4 and 5 add a number of bank characteristics. Columns 1-5 use clustering methods to correct standard errors for possible correlation between variables for banks in the same banking groups. Column 6 instead uses robust standard errors and replaces the country controls with country fixed effects. Controlling for individual bank characteristics and using standard clustered standard errors at the banking group level, we find that a shortfall-to-RWA of 1pp was associated with an annualized 9-month rate of loan growth that was $1 \mathrm{pp}$ to $1.1 \mathrm{pp}$ lower than for banks in the control group. Banks resident in 
"stressed" countries also tended to have lower lending growth. Of the bank characteristics included in the regression, only the deposit-to-loan ratio is significant. This ratio likely acts as an indicator of bank fragility, given that stressed banks were trying to strengthen their deposit base at this time following a period of dependence on short-term interbank funding. Also of note, the dummy variable EBA Banking Group, equal to one for a bank that was part of a group subjected to the Capital Exercise, is not significant in our regression analysis, indicating that there was no difference in annualized lending growth for the two categories of banks in our control sample, i.e., banks in groups that were identified as having a surplus in the capital exercise and banks that were not subject to the exercise.

These results suggest a limited impact of a reduction in leverage on lending growth in the short term, with a coefficient that is at the lower end of the range of estimates from the existing literature, as surveyed above in section 2. A number of factors may have dampened the magnitude of the impact in the present study, however. Most significantly, as discussed in section 3, the EBA and national supervisors exerted pressure on banks to increase their capital ratios mainlt through measures targeting their liabilities. Banks in a number of countries were also subject to other forms of "moral suasion" not to reduce lending at this time, notably from national politicians. The ECB also undertook exceptional liquidity-providing measures during this period, possibly reducing deleveraging pressure on banks.

Interpreting our results as indicating that the tightening in capital requirements induced the reduction in lending requires that we first discard an alternative reading related to potential information revelation by the EBA about the credit status of surveyed banks. Indeed, one may suppose that the main effect of the disclosure of detailed bank information by the EBA was to shed light on the fragility of some institutions, thus deterring potential investors and increasing the funding stress faced by these institutions. We provide evidence that this was not the case.

First, as previously stated, the banking groups included in the Capital Exercise were a subsample of the European banking groups already subject to the EBA stress tests in 2010 and 2011. In particular, the 2011 stress test, the conclusions of which were communicated to the pubic in the summer of 2011, already revealed most of the relevant information, including detailed exposures of participating institutions to sovereign debt holdings.

More formally, we conduct a small event study of the variation in CDS spreads of EBA banking groups over the date of the EBA disclosure in December 2011, when the EBA published bank-level results based on balance sheet data from end-September 2011. We 
Table 5: Impact of EBA Capital Exercise on Annualised Lending Growth: Oct 2011 - June 2012

\begin{tabular}{|c|c|c|c|c|c|c|}
\hline & 1 & 2 & 3 & 4 & 5 & 6 \\
\hline Truncated Shortfall/RWA & $\begin{array}{c}-1.36^{* *} \\
(0.53)\end{array}$ & $\begin{array}{c}-1.02^{* *} \\
(0.51)\end{array}$ & $\begin{array}{c}-1.21^{* *} \\
(0.47)\end{array}$ & $\begin{array}{l}-0.99^{*} \\
(0.51)\end{array}$ & $\begin{array}{c}-1.11^{* *} \\
(0.47)\end{array}$ & $\begin{array}{l}-0.95^{*} \\
(0.52)\end{array}$ \\
\hline Stressed & & $\begin{array}{c}-0.04^{* * *} \\
(0.01)\end{array}$ & & $\begin{array}{l}-0.02^{*} \\
(0.01)\end{array}$ & & \\
\hline Average Unemployment Rate & & & $\begin{array}{c}-0.28^{* * *} \\
(0.06)\end{array}$ & & $\begin{array}{c}-0.17^{* *} \\
(0.08)\end{array}$ & \\
\hline Size & & & & $\begin{array}{l}-0.00 \\
(0.00)\end{array}$ & $\begin{array}{c}0.00 \\
(0.00)\end{array}$ & $\begin{array}{l}-0.00 \\
(0.01)\end{array}$ \\
\hline Liquid Assets & & & & $\begin{array}{c}0.04 \\
(0.06)\end{array}$ & $\begin{array}{c}0.05 \\
(0.07)\end{array}$ & $\begin{array}{c}0.01 \\
(0.07)\end{array}$ \\
\hline Deposits to Assets & & & & $\begin{array}{c}0.08^{* * *} \\
(0.03)\end{array}$ & $\begin{array}{c}0.09^{* * *} \\
(0.03)\end{array}$ & $\begin{array}{l}0.08^{* *} \\
(0.03)\end{array}$ \\
\hline Loans to Assets & & & & $\begin{array}{l}-0.03 \\
(0.05)\end{array}$ & $\begin{array}{l}-0.03 \\
(0.05)\end{array}$ & $\begin{array}{l}-0.02 \\
(0.05)\end{array}$ \\
\hline Capital to Assets & & & & $\begin{array}{l}-0.02 \\
(0.10)\end{array}$ & $\begin{array}{l}-0.05 \\
(0.09)\end{array}$ & $\begin{array}{l}-0.13 \\
(0.13)\end{array}$ \\
\hline EBA Banking Group & & & & $\begin{array}{c}0.01 \\
(0.01)\end{array}$ & $\begin{array}{c}0.01 \\
(0.01)\end{array}$ & $\begin{array}{c}0.01 \\
(0.02)\end{array}$ \\
\hline Country Fixed Effects & No & No & No & No & No & Yes \\
\hline Clustered Standard Errors & Yes & Yes & Yes & Yes & Yes & No \\
\hline $\mathrm{N}$ & 198 & 198 & 198 & 198 & 198 & 198 \\
\hline $\mathrm{r} 2$ & 0.04 & 0.10 & 0.09 & 0.17 & 0.17 & 0.25 \\
\hline
\end{tabular}

Columns 1-6 present the results of our baseline regression specifications. Column 1 is a simple regression of annualised loan growth during the Capital Exercise on the Truncated Shortfall-toRWA ratio. Column 2 and 3 add our country control measures. Columns 4 and 5 add a number of bank characteristics. Columns 1-5 use clustering methods to correct standard errors for possible corrlation between variables for banks in the same banking groups. Column 6 insteads uses robust standard errors and replaces the country controls with country fixed effects. All specifications include a constant, which we do not present in the results. Standard errors are in parenthesis. Stars refer to the P-values as follows: $\mathrm{p}<0.10$ if $*, \mathrm{p}<0.05$ if $* *, \mathrm{p}<0.01$ if ***. 
find evidence that the market largely foresaw the degree of capital constraints faced by banks. More precisely, we calculate the shortfall-to-RWA ratio using data released on this date and use this as the independent variable in a regression explaining the change in banks' CDS spreads over windows of 1 to 3 days around the event date. The results, presented in Table 6, show that this announcement had a statistically significant impact on CDS spreads, especially at a 3-day horizon. The magnitude of this impact is very limited, however. While the CDS spread of the average bank in the sample increased by 36bps over the three days following the announcement, a bank with a shortfall-to-RWA of 1pp saw its CDS rise by just 3bps more. This confirms that the relevant story is not one of information about the situation of banks being revealed, and the markets penalizing these banks, but one where some banks faced a heightened regulatory capital constraint and adjusted their balance sheet accordingly over a short period.

Table 6: Impact of EBA Announcement on CDS Spreads: 8 December 2011

\begin{tabular}{lccc}
\hline \hline & 1-day & 2-day & 3-day \\
\hline Shortfall to RWA & $1.30^{* * *}$ & $2.24^{* * *}$ & $3.14^{* * *}$ \\
& $(0.37)$ & $(0.65)$ & $(0.78)$ \\
& & & \\
Constant & $12.82^{* * *}$ & $22.15^{* * *}$ & $36.04^{* * *}$ \\
& $(1.92)$ & $(2.96)$ & $(4.10)$ \\
\hline $\mathrm{N}$ & 43 & 43 & 43 \\
$\mathrm{r} 2$ & 0.14 & 0.18 & 0.17 \\
\hline \hline
\end{tabular}

Robust standard errors in parentheses

${ }^{*} p<0.10,{ }^{* *} p<0.05,{ }^{* * *} p<0.01$

\section{Robustness Tests}

In this section, we present the results of a number of robustness tests. The aim of these tests is twofold: firstly, to test the statistical robustness of our baseline results and, secondly, to determine whether the observed difference in loan growth rates between our two groups is really driven by the Capital Exercise. A fundamental assumption of difference-in-difference models is that outcomes for the treated and the control groups would have been the same in the absence of the treatment. ${ }^{21}$ In our case, we can state this hypothesis as follows: banks in groups identified as having capital shortfalls would not have had lower average

\footnotetext{
${ }^{21}$ This assumption is often denoted the "common or parallel trends" hypothesis. See Angrist and Pischke (2009, section 5.2).
} 
loan growth over the period of the Capital Exercise if they had not been subject to higher regulatory capital requirements as part of this exercise. It is, of course, impossible to test whether this hypothesis is true as we cannot observe the counterfactual for treated groups. However, the robustness tests that we undertake in this section, such as a placebo test and a change to our definition of the control group, provide evidence that this is indeed the case.

Our first robustness test is what is commonly referred to as a placebo test. Such a test undertakes the same regression specifications but on a different (non-overlapping) period in the sample in order to test whether the model identifies a statistically significant relationship during this period. Such a relationship would be difficult to interpret and would undermine the validity of our baseline results. Indeed, while the lower level of lending growth observed for our treated group may be due to deleveraging on the part of banks required to meet a higher regulatory capital requirement, it is also possible that weakly-capitalized banks would have undertaken necessary deleveraging even had the EBA exercise not taken place. We look at the 9-month window prior to the announcement of the stress tests (January 2011 - September 2011). The results of this regression (displayed in Table 7, which has the same structure as Table 5) show that the coefficient on the Truncated Shortfall-to-RWA ratio is not significant for this period. In contrast, a number of bank characteristics (the deposit-toasset ratio and the loan-to-asset ratio) do have a statistically significant relationship with lending growth during this period. These results support the hypothesis that the extra deleveraging observed by banks in our treatment group during the period of the Capital Exercise was due to the higher capital requirements imposed by this exercise.

Our second robustness test changes the composition of banks in our control group. In our baseline regression, we assume that banks in banking groups that were subject to the Capital Exercise and had a capital surplus exhibited similar lending behavior to banks that were not part of banking groups subject to the exercise, i.e., neither were subject to a regulatory capital adjustment. However, the results of our analysis should remain unchanged if we reduce the sample to include just banks that were in groups subject to the Capital Exercise. Table 8 shows the results of regressions undertaken with this reduced sample. As expected, the removal of these banks does not significantly change the magnitude of the coefficient or the standard error of the variable Truncated Shortfall-to-RWA, indicating that our results are robust to the size and composition of the control group.

Given the wide range of bank sizes in our sample, it is possible that our baseline regression results are skewed by the growth rates of small banks. We use weighted OLS analysis in order to test whether the results are robust to small banks being given a lower weight. 
Table 7: Placebo Regression: Impact of EBA Capital Exercise on Annualised Lending Growth: Jan 2011 - Sept 2011

\begin{tabular}{lcccccc}
\hline \hline & 1 & 2 & 3 & 4 & 5 & 6 \\
\hline Truncated Shortfall/RWA & -0.55 & -0.35 & -0.43 & -0.58 & -0.65 & -0.63 \\
Stressed & $(0.42)$ & $(0.45)$ & $(0.43)$ & $(0.47)$ & $(0.46)$ & $(0.55)$ \\
& & $-0.02^{*}$ & & -0.02 & & \\
Average Unemployment Rate & & $(0.01)$ & & $(0.02)$ & & \\
& & & $-0.20^{* *}$ & & -0.13 & \\
Size & & & & -0.01 & -0.01 & $-0.02^{* *}$ \\
& & & & $(0.01)$ & $(0.01)$ & $(0.01)$ \\
Liquid Assets & & & & 0.02 & 0.03 & -0.04 \\
& & & & $0.06)$ & $(0.06)$ & $(0.08)$ \\
Deposits to Assets & & & & $(0.02)$ & $(0.02)$ & $(0.03)$ \\
& & & & $-0.09^{*}$ & -0.09 & $-0.13^{*}$ \\
Loans to Assets & & & & $(0.05)$ & $(0.06)$ & $(0.07)$ \\
& & & & $0.49^{*}$ & $0.47^{*}$ & 0.39 \\
Capital to Assets & & & & $(0.28)$ & $(0.28)$ & $(0.32)$ \\
& & & & 0.01 & 0.01 & 0.02 \\
EBA Banking Group & & & & $(0.01)$ & $(0.01)$ & $(0.01)$ \\
& & & & & & \\
Country Fixed Effects & No & No & No & No & No & Yes \\
Clustered Standard Errors & Yes & Yes & Yes & Yes & Yes & No \\
& & & & & & \\
\hline N & 193 & 193 & 193 & 193 & 193 & 193 \\
r2 & 0.01 & 0.02 & 0.03 & 0.18 & 0.18 & 0.34 \\
\hline
\end{tabular}

Columns 1-6 present the results of our regression specifications for the 9-month period prior to the Capital Exercise. Column 1 is a simple regression of annualised loan growth during this period on the Truncated Shortfall-to-RWA ratio. Column 2 and 3 add our country control measures. Columns 4 and 5 add a number of bank characteristics. Columns 1-5 use clustering methods to correct standard errors for possible corrlation between variables for banks in the same banking groups. Column 6 insteads uses robust standard errors and replaces the country controls with country fixed effects. All specifications include a constant, which we do not present in the results. Standard errors are in parenthesis. Stars refer to the P-values as follows: $\mathrm{p}<0.10$ if *, $\mathrm{p}<0.05$ if **, $\mathrm{p}<0.01$ if ***. 
Table 8: Impact of EBA Capital Exercise on Annualised Lending Growth: Oct 2011 - June 2012 (excluding non-EBA groups)

\begin{tabular}{|c|c|c|c|c|c|c|}
\hline & 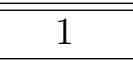 & 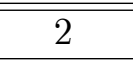 & 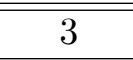 & 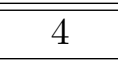 & 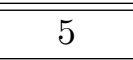 & 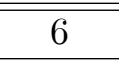 \\
\hline Truncated Shortfall/RWA & $\begin{array}{c}-1.48^{* *} \\
(0.58)\end{array}$ & $\begin{array}{c}-1.06^{*} \\
(0.59)\end{array}$ & $\begin{array}{c}-1.31^{* *} \\
(0.55)\end{array}$ & $\begin{array}{l}-0.98^{*} \\
(0.55)\end{array}$ & $\begin{array}{c}-1.15^{* *} \\
(0.51)\end{array}$ & $\begin{array}{l}-1.11 \\
(0.70)\end{array}$ \\
\hline Stressed & & $\begin{array}{c}-0.04^{* *} \\
(0.01)\end{array}$ & & $\begin{array}{l}-0.03 \\
(0.02)\end{array}$ & & \\
\hline Average Unemployment Rate & & & $\begin{array}{c}-0.23^{* *} \\
(0.10)\end{array}$ & & $\begin{array}{l}-0.10 \\
(0.12)\end{array}$ & \\
\hline Size & & & & $\begin{array}{c}0.00 \\
(0.00)\end{array}$ & $\begin{array}{c}0.00 \\
(0.00)\end{array}$ & $\begin{array}{c}0.00 \\
(0.01)\end{array}$ \\
\hline Liquid Assets & & & & $\begin{array}{c}0.09 \\
(0.06)\end{array}$ & $\begin{array}{c}0.09 \\
(0.07)\end{array}$ & $\begin{array}{c}0.05 \\
(0.08)\end{array}$ \\
\hline Deposits to Assets & & & & $\begin{array}{c}0.05 \\
(0.03)\end{array}$ & $\begin{array}{c}0.05 \\
(0.03)\end{array}$ & $\begin{array}{c}0.04 \\
(0.04)\end{array}$ \\
\hline Loans to Assets & & & & $\begin{array}{c}0.02 \\
(0.05)\end{array}$ & $\begin{array}{c}0.02 \\
(0.05)\end{array}$ & $\begin{array}{c}0.03 \\
(0.06)\end{array}$ \\
\hline Capital to Assets & & & & $\begin{array}{l}-0.15 \\
(0.10)\end{array}$ & $\begin{array}{c}-0.19^{* *} \\
(0.09)\end{array}$ & $\begin{array}{c}-0.25^{*} \\
(0.14)\end{array}$ \\
\hline Country Fixed Effects & No & No & No & No & No & Yes \\
\hline Clustered Standard Errors & Yes & Yes & Yes & Yes & Yes & No \\
\hline $\mathrm{N}$ & 124 & 124 & 124 & 124 & 124 & 124 \\
\hline r2 & 0.06 & 0.12 & 0.08 & 0.18 & 0.17 & 0.29 \\
\hline
\end{tabular}

Columns 1-6 present the results of our regression specifications using a subsample of banks, i.e., those that were part of banking groups subject to the Capital Exercise. Column 1 is a simple regression of annualised loan growth during the Capital Exercise on the Truncated Shortfall-to-RWA ratio. Column 2 and 3 add our country control measures. Columns 4 and 5 add a number of bank characteristics. Columns 1-5 use clustering methods to correct standard errors for possible corrlation between variables for banks in the same banking groups. Column 6 insteads uses robust standard errors and replaces the country controls with country fixed effects. All specifications include a constant, which we do not present in the results. Standard errors are in parenthesis. Stars refer to the P-values as follows: $\mathrm{p}<0.10$ if $*, \mathrm{p}<0.05$ if $* *, \mathrm{p}<0.01$ if $* * *$. 
Table 9 presents the results of this regression specification, with the size of the banks' loan books used as the weighting factor. The results show that the coefficient for the Truncated Shortfall-to-RWA ratio increases under this specification and also gains in significance.

Table 9: Impact of EBA Capital Exercise on Annualised Lending Growth: Oct 2011 - June 2012 (Weighted OLS)

\begin{tabular}{|c|c|c|c|c|c|c|}
\hline & 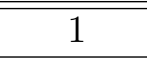 & 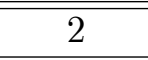 & 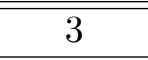 & 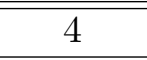 & 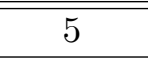 & 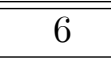 \\
\hline Truncated Shortfall/RWA & $\begin{array}{c}-2.25^{* * *} \\
(0.55)\end{array}$ & $\begin{array}{c}-1.54^{* * *} \\
(0.55)\end{array}$ & $\begin{array}{c}-1.93^{* * *} \\
(0.56)\end{array}$ & $\begin{array}{c}-1.62^{* * *} \\
(0.59)\end{array}$ & $\begin{array}{c}-1.94^{* * *} \\
(0.56)\end{array}$ & $\begin{array}{l}-0.95^{*} \\
(0.52)\end{array}$ \\
\hline Stressed & & $\begin{array}{c}-0.05^{* * *} \\
(0.01)\end{array}$ & & $\begin{array}{c}-0.04^{* * *} \\
(0.01)\end{array}$ & & \\
\hline Average Unemployment Rate & & & $\begin{array}{c}-0.27^{* * *} \\
(0.08)\end{array}$ & & $\begin{array}{l}-0.15^{*} \\
(0.09)\end{array}$ & \\
\hline Liquid Assets & & & & $\begin{array}{c}0.04 \\
(0.06)\end{array}$ & $\begin{array}{c}0.06 \\
(0.07)\end{array}$ & $\begin{array}{c}0.01 \\
(0.07)\end{array}$ \\
\hline Deposits to Assets & & & & $\begin{array}{l}0.07^{*} \\
(0.04)\end{array}$ & $\begin{array}{l}0.08^{* *} \\
(0.04)\end{array}$ & $\begin{array}{l}0.08^{* *} \\
(0.03)\end{array}$ \\
\hline Loans to Assets & & & & $\begin{array}{l}-0.02 \\
(0.06)\end{array}$ & $\begin{array}{l}-0.02 \\
(0.06)\end{array}$ & $\begin{array}{l}-0.02 \\
(0.04)\end{array}$ \\
\hline Capital to Assets & & & & $\begin{array}{l}-0.11 \\
(0.09)\end{array}$ & $\begin{array}{l}-0.20^{*} \\
(0.11)\end{array}$ & $\begin{array}{l}-0.13 \\
(0.13)\end{array}$ \\
\hline EBA Banking Group & & & & $\begin{array}{c}0.01 \\
(0.01)\end{array}$ & $\begin{array}{c}0.01 \\
(0.01)\end{array}$ & $\begin{array}{c}0.01 \\
(0.02)\end{array}$ \\
\hline Country Fixed Effects & No & No & No & No & No & Yes \\
\hline Clustered Standard Errors & Yes & Yes & Yes & Yes & Yes & No \\
\hline $\mathrm{N}$ & 198 & 198 & 198 & 198 & 198 & 198 \\
\hline r2 & 0.15 & 0.28 & 0.23 & 0.32 & 0.30 & 0.25 \\
\hline
\end{tabular}

Columns 1-6 present the results of our regression specifications using weighted OLS. Banks' total loans are used as the weighting factor. Column 1 is a simple regression of annualised loan growth during the Capital Exercise on the Truncated Shortfall-to-RWA ratio. Column 2 and 3 add our country control measures. Columns 4 and 5 add a number of bank characteristics. Columns 1-5 use clustering methods to correct standard errors for possible corrlation between variables for banks in the same banking groups. Column 6 insteads uses robust standard errors and replaces the country controls with country fixed effects. All specifications include a constant, which we do not present in the results. Standard errors are in parenthesis. Stars refer to the P-values as follows: $p<0.10$ if $*, \mathrm{p}<0.05$ if **, $\mathrm{p}<0.01$ if ***.

Our final robustness test attempts to correct for the possibility of correlation between the observations for banks in the same banking group. In our baseline analysis, we account for the possibility of such correlation by correcting our standard errors using clustering 
methods. Another method is to average observations at a group level. We therefore collapse our dataset into 118 groups by averaging the variables in our regression specification. We also construct a variable Lending to Stressed Countries, corresponding to the proportion of each group's lending in "stressed" euro area countries. ${ }^{22}$ The results of these regressions are shown in Table 10 and indicate that our results are robust to correlation among banks in groups. However, while the coefficient on our Shortfall-to-RWA variable remains significant, its magnitude decreases by almost a third.

\section{Timing of Effects}

The results of our placebo test, presented in Table 7, show that banks in groups with a capital shortfall did not undertake preemptive deleveraging prior to the announcement of the Capital Exercise. This underlines the unexpected nature of the Capital Exercise. It is also interesting to investigate whether the Capital Exercise had any enduring effect on bank lending behaviour. Intuitively, there is no reason to believe that this would have been the case: once banks reached the higher regulatory capital requirement, they did not need to adjust their risk-weighed assets any further. We undertake a second placebo test on the 12month period immediately following the Capital Exercise (July 2012 - June 2013) in order to investigate whether this was indeed the case. Our results are presented in Table 11. In these regressions, none of the coefficients on the Truncated Shortfall-to-RWA variable are statistically significant, suggesting that the level of the group capital shortfall did not have any impact on the lending behabiour of constitutent banks once the new regulatory capital ratios had been reached. It would therefore appear that this increase in regulatory capital requirements did not have a persistent effect on lending behaviour. This closely resembles the results of Bridges et al. (2014), who find no significant long-run impact on lending growth for a range of loan categories from an increase in regulatory capital requirements. Our results suggest that the Capital Exercise did, however, have a persistent effect on the stock of lending as banks in shortfall groups did not rapidly compensate for their lower levels of lending growth during the exercise, as Figure 1 also suggests. The results of this second placebo test also further strengthen our conclusion that the difference in lending behaviour between banks in shortfall and surplus groups over the course of the Capital Exercise was indeed driven by the increase in regulatory capital requirements.

\footnotetext{
${ }^{22}$ It is important to note our dataset does not allow us to recreate consolidated group balance sheets by aggregating constituent banks' balance sheets. This is due to the fact that the IBSI dataset does not necessarily contain data for all banks in a banking group.
} 
Table 10: Impact of EBA Capital Exercise on Lending Growth: Oct 2011 - June 2012 (Group Averages)

\begin{tabular}{lccc}
\hline \hline & 1 & 2 & 3 \\
\hline Truncated Shortfall/RWA & $-1.21^{* * *}$ & $-0.70^{*}$ & $-0.67^{*}$ \\
& $(0.42)$ & $(0.40)$ & $(0.39)$ \\
Exposure to Stressed Countries & & $-0.04^{* * *}$ & $-0.02^{*}$ \\
Size & & $(0.01)$ & $(0.01)$ \\
& & & -0.00 \\
Liquid Assets & & $(0.01)$ \\
& & & 0.04 \\
Deposits to Assets & & & $0.09)$ \\
& & & $0.11^{* *}$ \\
Loans to Assets & & & $-0.05)$ \\
& & & 0.11 \\
Capital to Assets & & & 0.07 \\
& & & $-0.22)$ \\
EBA Banking Group & & & $(0.01)$ \\
& & & \\
Fixed effects & No & No \\
Clustered Standard Errors & No & No & No \\
& & & \\
\hline N & 118 & 118 & 118 \\
r2 & 0.05 & 0.14 & 0.29 \\
\hline \hline
\end{tabular}

Columns 1-3 present the results of our regression specifications using variables that have been averaged at the banking group level. Column 1 is a simple regression of annualised loan growth during the Capital Exercise on the Truncated Shortfall-to-RWA ratio. Column 2 adds the vairable Exposure to Stressed Countries, which represents the proportion of groups' lending activity in euro area countries experiencing stress on their sovereign bond market. Column 3 adds a number of bank characteristics. All specifications include a constant, which we do not present in the results. Standard errors are in parenthesis. Stars refer to the P-values as follows: $\mathrm{p}<0.10$ if $*, \mathrm{p}<0.05$ if $* *, \mathrm{p}<0.01$ if $* * *$. 
Table 11: Second Placebo Regression: Impact of EBA Capital Exercise on Annualised Lending Growth: July 2012 - June 2013

\begin{tabular}{|c|c|c|c|c|c|c|}
\hline & $\overline{1} 1$ & 2 & 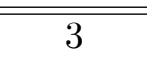 & 4 & 5 & 6 \\
\hline Truncated Shortfall/RWA & $\begin{array}{l}-0.86 \\
(0.53)\end{array}$ & $\begin{array}{l}-0.48 \\
(0.53)\end{array}$ & $\begin{array}{l}-0.59 \\
(0.50)\end{array}$ & $\begin{array}{l}-0.29 \\
(0.56)\end{array}$ & $\begin{array}{l}-0.38 \\
(0.52)\end{array}$ & $\begin{array}{l}-0.53 \\
(0.65)\end{array}$ \\
\hline Stressed & & $\begin{array}{c}-0.05^{* * *} \\
(0.01)\end{array}$ & & $\begin{array}{c}-0.04^{* * *} \\
(0.01)\end{array}$ & & \\
\hline Average Unemployment Rate & & & $\begin{array}{c}-0.31^{* * *} \\
(0.06)\end{array}$ & & $\begin{array}{c}-0.29^{* * *} \\
(0.11)\end{array}$ & \\
\hline Size & & & & $\begin{array}{c}0.00 \\
(0.00)\end{array}$ & $\begin{array}{c}0.00 \\
(0.00)\end{array}$ & $\begin{array}{c}0.00 \\
(0.01)\end{array}$ \\
\hline Liquid Assets & & & & $\begin{array}{c}0.07 \\
(0.08)\end{array}$ & $\begin{array}{c}0.09 \\
(0.08)\end{array}$ & $\begin{array}{c}0.07 \\
(0.09)\end{array}$ \\
\hline Deposits to Assets & & & & $\begin{array}{l}0.06^{*} \\
(0.04)\end{array}$ & $\begin{array}{l}0.06^{*} \\
(0.04)\end{array}$ & $\begin{array}{c}0.05 \\
(0.03)\end{array}$ \\
\hline Loans to Assets & & & & $\begin{array}{c}0.04 \\
(0.06)\end{array}$ & $\begin{array}{c}0.05 \\
(0.06)\end{array}$ & $\begin{array}{c}0.05 \\
(0.06)\end{array}$ \\
\hline Capital to Assets & & & & $\begin{array}{c}0.00 \\
(0.12)\end{array}$ & $\begin{array}{l}-0.04 \\
(0.11)\end{array}$ & $\begin{array}{l}-0.01 \\
(0.14)\end{array}$ \\
\hline EBA Banking Group & & & & $\begin{array}{l}-0.00 \\
(0.01)\end{array}$ & $\begin{array}{l}-0.00 \\
(0.01)\end{array}$ & $\begin{array}{l}-0.00 \\
(0.01)\end{array}$ \\
\hline Country Fixed Effects & No & No & No & No & No & Yes \\
\hline Clustered Standard Errors & Yes & Yes & Yes & Yes & Yes & No \\
\hline $\mathrm{N}$ & 193 & 193 & 193 & 193 & 193 & 193 \\
\hline $\mathrm{r} 2$ & 0.01 & 0.12 & 0.09 & 0.18 & 0.17 & 0.24 \\
\hline
\end{tabular}

Columns 1-6 present the results of our regression specifications for the 12-month period following the Capital Exercise. Column 1 is a simple regression of annualised loan growth during this period on the Truncated Shortfall-to-RWA ratio. Column 2 and 3 add our country control measures. Columns 4 and 5 add a number of bank characteristics. Columns 1-5 use clustering methods to correct standard errors for possible corrlation between variables for banks in the same banking groups. Column 6 insteads uses robust standard errors and replaces the country controls with country fixed effects. All specifications include a constant, which we do not present in the results. Standard errors are in parenthesis. Stars refer to the P-values as follows: $\mathrm{p}<0.10$ if ${ }^{*}, \mathrm{p}<0.05$ if **, $\mathrm{p}<0.01$ if ${ }^{* * *}$. 


\section{Looking for Aggregate Effects}

The results presented in Section 5 indicate that the increase in regulatory capital levels as part of the EBA's Capital Exercise led to lower rates of loan growth during the period of the exercise for banks identified as having a capital shortfall. It is possible, however, that this reduced rate of loan growth by shortfall banks was compensated for by other banks, resulting in little or no impact on overall loan growth at a country or euro area level. We investigate this hypothesis by collapsing our dataset at a country level and constructing the variable Weighted Shortfall-to-RWA, which is equal to the weighted average of banks' Shortfall-to-RWA ratios (weighted by the size of banks' loan books) during the period of the Capital Exercise and zero otherwise. We compute credit growth rates as the country average of the "clean" growth rates we computed for individual banks present in a given country. ${ }^{23}$

The results of this analysis are presented in Table 12 . Column 1 is a simple regression of monthly growth rates of credit at the country level on the weighted shortfall-to-rwa and unemployment. Column 2 replaces unemployment with country and time fixed effects. Column 3 adds a lag of the dependent variable. ${ }^{24}$ Column 4 clusters standard errors at the country level as a straightforward way to correct them for possible correlation (including auto-correlation in the time dimension) between observations in the same country. The coefficients for the variable Weighted Shortfall-to-RWA is significant across all 4 specifications and at least as large as at the micro level, indicating that the Capital Exercise did indeed have a negative impact on country-level lending growth over the horizon of the exercise.

\footnotetext{
${ }^{23}$ An alternative could be to look at aggregate growth rates of domestic credit to the non-financial private sector from country-level monetary statistics releases. As banks in our sample account for the bulk of credit in most countries, the results would be qualitatively unchanged.

${ }^{24}$ The presence of both lagged dependent variables and fixed effects causes a well-known bias in the coefficient of the lagged dependent variable. However, since we include more than 30 monthly observations and as our sample of countries is small, standard fixed effects remains preferable to Generalised Method of Moments (GMM). Besides, preliminary checks showed that monthly credit growth rates are barely autocorrelated at the country level (with correlation coefficients between 0 and 0.3). Cf. Judson and Owen (1999) for a formal justification.
} 
Table 12: Impact of Shortfall Banks on Country-Level Loan Growth: Jan 2010 - Dec 2012

\begin{tabular}{lcccc}
\hline \hline & 1 & 2 & 3 & 4 \\
\hline Weighted Shortfall-to-RWA & $-0.93^{* * *}$ & $-1.91^{* *}$ & $-1.99^{* *}$ & $-1.99^{* * *}$ \\
& $(0.24)$ & $(0.76)$ & $(0.78)$ & $(0.46)$ \\
Unemployment & $-0.01^{* * *}$ & & & \\
& $(0.00)$ & & & \\
Lagged dep. var. & & & -0.03 & -0.03 \\
& & & $(0.04)$ & $(0.03)$ \\
Fixed effects & No & Yes & Yes & Yes \\
Clustered Standard Errors & No & No & No & Yes \\
& & & & \\
\hline $\mathrm{N}$ & 564 & 564 & 540 & 540 \\
$\mathrm{r} 2$ & 0.06 & 0.38 & 0.38 & 0.38 \\
\hline \hline
\end{tabular}

Columns 1-4 present the results of country-level regressions with annualised 1month loan growth as the dependent variable. WeightedShortfall-to-RWA is the average shortfall-to-rwa of each bank in the country weighted by the size of banks' loanbooks. This variable is equal to zero for all months outside the 9-month period of the Capital Exercise. Column 1 is a simple regression using the weighted shortfall-to-rwa and unemployment. Column 2 replaces unemployment with country and time fixed effects. Column 3 adds a lag of the dependent variable. Column 4 uses clustering methods to correct standard errors for possible corrlation between observations in the same country. Standard errors are in parenthesis. Stars refer to the P-values as follows: $\mathrm{p}<0.10$ if $*$, $\mathrm{p}<0.05$ if $* *, \mathrm{p}<0.01$ if $* * *$. 


\section{Conclusions}

We use the EBA's recent recapitalization exercise as a natural experiment to test the impact of a regulatory shock tightening bank capital requirements on lending to the real economy. For this purpose, we exploit a new dataset of monthly balance sheets of some 240 individual banks (representative of credit provision at both the euro area and Member States levels) and map it onto data for the banking groups monitored by the EBA. Controlling for individual bank characteristics and demand at the level of country of residence, we find that forcing a banking group to increase its Core Tier 1 capital by 1 percent of risk-weighted assets was associated with a decrease of 1.1 percent (annualized) in credit supplied by banks in the same group over the 9-month period of the Capital Exercise. We find no evidence of persistence in this effect, however. We also collapse our dataset at the country level in order to assess aggregate effects and find that banks that were not constrained to recapitalize did not substitute for more constrained lenders. This confirms that the Exercise had procyclical macroeconomic effects on credit supply. At the same time, the magnitude of the effects that we find are at the lower range of the effects of regulatory capital shocks on credit supply found in the empirical literature. This may be accounted for by the expansionary measures implemented by the Eurosystem over the same period of time. Also, this may suggest that moral suasion by supervisors and governments was indeed instrumental in convincing major banking groups with a capital shortfall to limit their shedding of risk weighted assets.

Two words of caution are nevertheless of the essence when interpreting these results. First, we emphasize that our study only documents the short run contractionary effect of an unexpected tightening of capital requirements on bank lending. Second, we confirm that the EBA Capital Exercise was badly timed and therefore procyclical, as it took place in a context of depressed activity and declining lending trends. However, our findings should not be interpreted as pointing to permanent contractionary effects of heightened capital requirements or as suggesting that even short run effects would be as large if the tightening was imposed during more benign times. At the same time, our findings tend to strengthen the case for a gradual implementation of stricter bank regulations, thus allowing banks to meet heightened capital ratios mostly by the accumulation of retained earnings. Lastly, comparing the EBA Exercise to the SCAP recapitalization program of the US Federal Reserve in 2009 (as a result of the stress tests), we can also view our results as highlighting the potential benefits of bank recapitalization programs that are targeted at capital levels (or in "euros") rather than at capital ratios, especially when this equity adjustment has to 
happen in crisis times. ${ }^{25}$

Last but not least, our study sheds some useful light on decisions facing the ECB in its new role as the euro area's Single Supervisory Mechanism (SSM) when it comes to draw lessons for its ongoing Asset Quality Review of the balance sheets of large euro area bank holding companies. Indeed, demanding that banks hold capital against their sovereign assets, as outlined recently by the new head of the SSM, amounts to a regulatory tightening that is very similar to the EBA Exercise. To the extent that these new capital weights lead to capital requirements in excess of the capital buffer already held by banks, and supposing that monetary policy remains as accommodative as it currently is, our estimates could provide an upper bound of the expected negative effects on credit supply in the zone.

\footnotetext{
${ }^{25}$ The case for recapitalization objectives targeted at "dollars" of capital instead of capital ratios is made by Hanson, Kashyap and Stein (2011). They notably point out that in the few months following the release of the SCAP results, the banks involved were able to raise over $\$ 125$ billion of new equity, without apparent negative impact on credit supply. As they emphasize, the tough hand of the regulator, which left no room for discretionary action, made this issuance easier for banks by removing the usual moral hazard problem à la Myers and Majluf (1984).
} 


\section{A Data}

\section{A.1 Definition and sources of bank variables}

\begin{tabular}{|c|c|}
\hline Statistic & Description \\
\hline Size & $\begin{array}{l}\text { Total Assets of banks (in euros). These figures are } \\
\text { converted to logs when used in our regression analysis. }\end{array}$ \\
\hline $\begin{array}{l}\text { Annualised Loan Growth (Re- } \\
\text { cap Period) }\end{array}$ & $\begin{array}{l}\text { Annualised 9-month loan growth over the period of } \\
\text { the Capital Exercise (October } 2011 \text { to June 2012). }\end{array}$ \\
\hline Loans to Assets & $\begin{array}{l}\text { Total loans to the real economy (sum of Loans to } \\
\text { Households and Loans to Non-financial Corporates) } \\
\text { divided by Total Assets. }\end{array}$ \\
\hline Capital to Assets & $\begin{array}{l}\text { Capital divided by Total Assets. The capital figure in } \\
\text { the IBSI dataset is a broad measure of banks' capital, } \\
\text { including equity capital raised, undistributed profits, } \\
\text { and provision against loans and other types of assets. }\end{array}$ \\
\hline Liquid Assets & $\begin{array}{l}\text { Sum of Interbank Desposits and Sovereign Debt Hold- } \\
\text { ings divided by Total Assets. Interbank Deposits in- } \\
\text { clude liquidity deposited with the Eurosystem. }\end{array}$ \\
\hline Deposits to Assets & $\begin{array}{l}\text { Real economy deposits (sum of Deposits from House- } \\
\text { holds and Deposits from Non-financial Corporates) di- } \\
\text { vided by Total Assets. }\end{array}$ \\
\hline Interbank Liabilities to Assets & $\begin{array}{l}\text { Borrowings from other banks (Interbank Loans) di- } \\
\text { vided by Total Assets. Interbank Loans include bor- } \\
\text { rowing from the Eurosystem, }\end{array}$ \\
\hline Desposits to Loans & $\begin{array}{l}\text { Total deposits from the real economy (sum of Deposits } \\
\text { from Households and Deposits from Non-Financial } \\
\text { Corporates) divided by total loans to the real econ- } \\
\text { omy (sum of Loans to Households and Loans to Non- } \\
\text { Financial corporates). We report the inverse of the } \\
\text { more commonly used Loans-to-Deposits ratio due the } \\
\text { presence of non deposit taking banks in our sample. }\end{array}$ \\
\hline
\end{tabular}




\section{A.2 List of Banking Groups in Sample}

Table A.1: List of Groups in Sample

\begin{tabular}{|c|c|c|c|c|}
\hline Nationality & Head ID Code & EBA ID Code & Bank Group Name & Number Banks \\
\hline AT & AT14000 & & $\begin{array}{l}\text { BAWAG P.S.K. Bank für Arbeit und Wirtschaft } \\
\text { und Österreichische Postsparkasse Aktienge- } \\
\text { sellschaft }\end{array}$ & 1 \\
\hline $\mathrm{AT}$ & AT15000 & & Oberbank AG & 1 \\
\hline $\mathrm{AT}$ & AT20100 & AT001 & Erste Group Bank (EGB) & 3 \\
\hline $\mathrm{AT}$ & AT31000 & AT002 & Raiffeisen Zentralbank Österreich (RZB) & 2 \\
\hline $\mathrm{AT}$ & AT32000 & & Raiffeisenlandesbank Niederoesterreich-Wien AG & 1 \\
\hline AT & AT34000 & & $\begin{array}{l}\text { Raiffeisenlandesbank Oberösterreich Aktienge- } \\
\text { sellschaft }\end{array}$ & 1 \\
\hline $\mathrm{BE}$ & BEARSPBE22 & & N.V. Argenta Spaarbank & 1 \\
\hline $\mathrm{BE}$ & BEARTEBEBB & & Belfius Banque SA & 1 \\
\hline $\mathrm{BE}$ & BEKREDBEBB & BE005 & $\mathrm{KBC}$ BANK & 2 \\
\hline $\mathrm{CY}$ & CY110002 & CY007 & Bank of Cyprus Public Company Ltd & 1 \\
\hline $\mathrm{CY}$ & CY110003 & & $\begin{array}{l}\text { Co-operative Central Bank Ltd (CY110003) and } \\
\text { Co-operative credit institutions [aggregated] }\end{array}$ & 1 \\
\hline $\mathrm{CY}$ & CY110005 & & Hellenic Bank Public Company Ltd & 1 \\
\hline $\mathrm{CY}$ & CY110010 & CY006 & Marfin Popular Bank Public Co Ltd & 1 \\
\hline $\mathrm{DE}$ & DE00001 & DE017 & Deutsche Bank Aktiengesellschaft & 7 \\
\hline $\mathrm{DE}$ & DE00003 & DE018 & Commerzbank AG & 3 \\
\hline DE & DE00091 & & Oldenburgische Landesbank Aktiengesellschaft & 1 \\
\hline $\mathrm{DE}$ & DE00316 & DE019 & Landesbank Baden-Wuerttemberg & 1 \\
\hline $\mathrm{DE}$ & DE00317 & DE021 & Bayerische Landesbank & 2 \\
\hline DE & DE00319 & DE026 & Landesbank Hessen-Thüringen Girozentrale & 2 \\
\hline $\mathrm{DE}$ & DE00320 & DE022 & Norddeutsche Landesbank-Girozentrale & 3 \\
\hline $\mathrm{DE}$ & DE00325 & & Nassauische Sparkasse & 1 \\
\hline $\mathrm{DE}$ & DE00561 & & Stadtsparkasse Muenchen & 1 \\
\hline $\mathrm{DE}$ & DE00637 & DE027 & Landesbank Berlin AG & 2 \\
\hline DE & DE00724 & & Sparkasse Hannover & 1 \\
\hline $\mathrm{DE}$ & DE00835 & & Stadtsparkasse Essen & 1 \\
\hline $\mathrm{DE}$ & DE00897 & & Sparkasse KoelnBonn / & 2 \\
\hline $\mathrm{DE}$ & DE01094 & & Sparkasse Suedholstein & 1 \\
\hline $\mathrm{DE}$ & DE01108 & & Die Sparkasse Bremen AG & 1 \\
\hline $\mathrm{DE}$ & DE01109 & & Hamburger Sparkasse AG & 1 \\
\hline $\mathrm{DE}$ & DE01121 & DE020 & DZ Bank AG Dt. Zentral-Genossenschaftsbank & 3 \\
\hline $\mathrm{DE}$ & DE01127 & DE029 & WGZ Bank AG Westdt. Geno. Zentralbk, Ddf & 2 \\
\hline $\mathrm{DE}$ & DE01135 & & Deutsche Apotheker- und Ärztebank eG & 1 \\
\hline $\mathrm{DE}$ & DE01244 & & Volksbank Pforzheim eG. & 1 \\
\hline $\mathrm{DE}$ & DE01291 & & Volksbank Stuttgart eG & 1 \\
\hline
\end{tabular}


Table A.2: List of Groups in Sample (Cont'd)

\begin{tabular}{|c|c|c|c|c|}
\hline Nationality & Head ID Code & EBA ID Code & Bank Group Name & Number Banks \\
\hline $\mathrm{DE}$ & DE01364 & & Muenchner Bank eG & 1 \\
\hline $\mathrm{DE}$ & DE01400 & & Berliner Volksbank eG & 1 \\
\hline DE & DE01436 & & Frankfurter Volksbank eG & 1 \\
\hline DE & DE01521 & & Hannoversche Volksbank eG & 1 \\
\hline $\mathrm{DE}$ & DE01776 & & Sparda-Bank Suedwest eG & 1 \\
\hline $\mathrm{DE}$ & DE03249 & & Deutsche Pfandbriefbank AG & 1 \\
\hline $\mathrm{DE}$ & DE03250 & & Muenchener Hypothekenbank eG & 1 \\
\hline $\mathrm{DE}$ & DE03402 & & $\begin{array}{l}\text { Volkswagen Bank Gesellschaft mit beschränkter } \\
\text { Haftung }\end{array}$ & 1 \\
\hline $\mathrm{DE}$ & DE03472 & & Aareal Bank AG & 1 \\
\hline $\mathrm{DE}$ & DE05695 & & $\begin{array}{l}\text { Landeskreditbank Baden-Wuerttemberg - Fo- } \\
\text { erderbank - }\end{array}$ & 1 \\
\hline $\mathrm{DE}$ & DE05740 & & NRW. Bank & 1 \\
\hline $\mathrm{DE}$ & DE05749 & DE025 & HSH Nordbank AG & 1 \\
\hline $\mathrm{DE}$ & DE06261 & & Ostsaechsische Sparkasse Dresden & 1 \\
\hline $\mathrm{DE}$ & DE06273 & & Stadt- und Kreissparkasse Leipzig & 1 \\
\hline DK & DK003000 & DK008 & Danske Bank & 4 \\
\hline ES & ES0049 & ES059 & Banco Santander S.A. & 6 \\
\hline ES & ES0075 & ES064 & Banco Popular Español, S.A. & 1 \\
\hline $\mathrm{ES}$ & ES0081 & & Banco de Sabadell, S.A. & 1 \\
\hline ES & ES0128 & & Bankinter, S.A. & 1 \\
\hline ES & ES0182 & ES060 & Banco Bilbao Vizcaya Argentaria, S.A. & 1 \\
\hline ES & ES1000 & & Instituto de Crédito Oficial & 1 \\
\hline ES & ES2048 & & Liberbank, S.A & 1 \\
\hline ES & ES2085 & & Ibercaja Banco, S.A & 1 \\
\hline ES & ES2095 & & Kutxabank, S.A. & 1 \\
\hline ES & ES2100 & & CaixaBank, S.A & 1 \\
\hline $\mathrm{ES}$ & ES2103 & & Unicaja Banco, S.A & 1 \\
\hline ES & ES2108 & & $\begin{array}{l}\text { Banco de Caja España de Inversiones, Salamanca } \\
\text { y Soria, SA }\end{array}$ & 1 \\
\hline ES & ES3058 & & Cajas Rurales Unidas & 1 \\
\hline ES & frob & & FROB & 4 \\
\hline FI & FI01999207 & FI012 & OP-Pohjola Group & 2 \\
\hline FI & FI21817028 & & $\begin{array}{l}\text { Aktia Bank Abp (FI21817028) and Savings banks } \\
\text { [aggregated] }\end{array}$ & 1 \\
\hline FR & FR10278 & & Targobank AG \& Co. KGaA & 1 \\
\hline FR & FR11808 & & Banque Fédérative du Crédit Mutuel & 3 \\
\hline FR & FR12548 & & AXA Bank Europe SA & 1 \\
\hline FR & FR16188 & FR015 & $\mathrm{BPCE}$ & 10 \\
\hline FR & FR19460 & & Sofax banque & 1 \\
\hline FR & FR20041 & & La Banque Postale & 1 \\
\hline FR & FR30003 & FR016 & Societe Generale & 4 \\
\hline FR & FR30004 & FR013 & BNP Paribas & 5 \\
\hline FR & FR30006 & FR014 & Credit Agricole & 6 \\
\hline GB & GB0570 & GB090 & Barclays plc & 4 \\
\hline GB & GB1805 & GB089 & HSBC Holdings plc & 2 \\
\hline GB & GB2600 & GB088 & Royal Bank of Scotland Group plc & 2 \\
\hline IE & IEAIBPLC & IE037 & Allied Irish Banks PLC & 1 \\
\hline IE & IEANGLOI & & Irish Bank Resolution Corporation Limited & 1 \\
\hline IE & IEBKIREL & IE038 & $\begin{array}{l}\text { THE Governor and Company of the Bank of Ire- } \\
\text { land }\end{array}$ & 2 \\
\hline IE & IEIRPERM & IE039 & Irish Life and Permanent PLC & 1 \\
\hline
\end{tabular}


Table A.3: List of Groups in Sample (Cont'd)

\begin{tabular}{|c|c|c|c|c|}
\hline Nationality & Head ID Code & EBA ID Code & Bank Group Name & Number Banks \\
\hline IT & IT01030 & IT042 & BancaA Monte dei Paschi di Siena Spa & 2 \\
\hline IT & IT02008 & IT041 & Unicredit Banca Spa & 4 \\
\hline IT & IT03032 & & Credito Emiliano Spa & 1 \\
\hline IT & IT03069 & IT040 & Intesa Sanpaolo Spa & 4 \\
\hline $\mathrm{IT}$ & IT03111 & IT044 & Unione di Banche Italiane SCPA (UBI Banca) & 2 \\
\hline IT & IT05035 & & $\begin{array}{l}\text { Veneto Banca Holding Societa' Cooperativa per } \\
\text { Azioni }\end{array}$ & 1 \\
\hline IT & IT05387 & & Banca Popolare dell'Emilia Romagna & 1 \\
\hline IT & IT05584 & & Banca Popolare di Milano & 1 \\
\hline IT & IT05696 & & $\begin{array}{l}\text { Banca Popolare di Sondrio Societa Cooperativa } \\
\text { per Azioni }\end{array}$ & 1 \\
\hline IT & IT05728 & & $\begin{array}{l}\text { Banca Popolare di Vicenza Societa Cooperativa } \\
\text { per Azioni }\end{array}$ & 1 \\
\hline $\mathrm{IT}$ & IT06055 & & Banca delle Marche Spa & 1 \\
\hline $\mathrm{IT}$ & IT06175 & & $\begin{array}{l}\text { Banca Carige Spa - Cassa di Risparmio di Genova } \\
\text { e Imperia }\end{array}$ & 1 \\
\hline IT & IT10631 & & Mediobanca - Banca di Credito Finanziario Spa & 1 \\
\hline $\mathrm{LU}$ & LUB00001 & LU045 & $\begin{array}{l}\text { Banque et Caisse d'Epargne de l'Etat, Luxem- } \\
\text { bourg }\end{array}$ & 1 \\
\hline LU & LUB00009 & & Banque Raiffeisen & 1 \\
\hline MT & MTCIAPSB & & APS Bank Ltd & 1 \\
\hline MT & MTCILBMA & & Lombard Bank Malta plc & 1 \\
\hline MT & MTCIVALL & MT046 & Bank of Valletta plc & 1 \\
\hline NL & NL120 & & F. van Lanschot Bankiers N.V. & 1 \\
\hline NL & NL149 & NL049 & ABN Amro Bank N.V. & 1 \\
\hline NL & NL163 & NL047 & ING Bank NV & 6 \\
\hline NL & NL399 & & Achmea Bank Holding N.V & 1 \\
\hline NL & NL512 & & The bank of Tokyo - Mitsubishi UFJ Ltd & 1 \\
\hline NL & NL578 & NL050 & SNS Bank N.V. & 1 \\
\hline NL & NL600 & NL048 & Rabobank Nederland & 4 \\
\hline NL & NL680 & & Bank Nederlandse Gemeenten N.V. & 1 \\
\hline $\mathrm{PT}$ & PT10 & PT056 & Banco BPI, SA & 1 \\
\hline $\mathrm{PT}$ & PT33 & PT054 & Banco Comercial Português, SA & 1 \\
\hline $\mathrm{PT}$ & PT35 & РT053 & Caixa Geral de Depósitos, SA & 1 \\
\hline $\mathrm{PT}$ & PT7 & PT055 & Banco Espírito Santo, SA & 1 \\
\hline $\mathrm{SE}$ & SE11102 & SE085 & Skandinaviska Enskilda Banken AB (publ) (SEB) & 2 \\
\hline $\mathrm{SE}$ & SE11123 & SE086 & Svenska Handelsbanken AB (publ) & 1 \\
\hline $\mathrm{SE}$ & SE11145 & SE084 & Nordea Bank AB (publ) & 2 \\
\hline $\mathrm{SE}$ & SE11200 & SE087 & Swedbank AB (publ) & 1 \\
\hline SI & SI5026024 & & Abanka Vipa D.D. & 1 \\
\hline SI & SI5860571 & SI057 & Nova Ljubljanska Banka D.D., Ljubljana & 1 \\
\hline SI & SI5860580 & SI058 & Nova Kreditna Banka Maribor D.D. & 1 \\
\hline
\end{tabular}




\section{References}

[1] Admati, A.R., P.M. DeMarzo, M.F. Hellwig, and P. Pfleiderer (2010), "Fallacies, Irrelevant Facts, and Myths: Why Bank Equity is not Expensive", mimeo, Stanford and Bonn.

[2] Albertazzi, U. and D.J. Marchetti (2010), "credit supply, flight to quality and evergreening: an analysis of bank-firm relationships after Lehman," Temi di discussione 756, Bank of Italy.

[3] Ashcraft, A.B. (2008), "Are Bank Holding Companies a Source of Strength to Their Banking Subsidiaries?," Journal of Money, Credit and Banking, vol. 40(2-3), pages 273-294, 03 .

[4] Aiyar, S., Calomiris , C.W., and T. Wieladek (2012), "Does macropru leak? Evidence from a UK policy experiment," Bank of England working papers 445, Bank of England.

[5] Basel Committee on Banking Supervision (2010), "The Basel Committee's response to the financial crisis: report to the G20". BIS-BCBS, October.

[6] Bassett, W., and F. Covas (2012), "A new look at the relationship between capital constraints and bank lending". Mimeo, Federal Reserve Board.

[7] Berrospide, J., and R. E. Edge (2010), "The effects of bank capital on lending : What do we know? And, what does it mean?", International Journal of Central Banking, 6 (4), $5-55$.

[8] Bernanke, B.S., and C. Lown (1991), "The credit crunch", Brookings Papers on Economic Activity, 2, 205-247.

[9] Bridges, J., Gregory, D., Nielsen, M., Pezzini, S., Amar, R. and M. Spaltro (2014), "The Impact of Capital Requirements on Bank Lending", Bank of England Working Paper No. 486.

[10] Brun, M., Fraisse, H., and D. Thesmar (2014), "The effects of bank capital requirements", Autorité de Contrôle Prudentiel et de Résolution, Working Paper.

[11] Ehrmann, M. and A. Worms (2004), "Bank Networks and Monetary Policy Transmission," Journal of the European Economic Association, MIT Press, vol. 2(6), pages 1148-1171, December. 
[12] Francis, W.B., and M. Osborne (2009), "Bank regulation, capital and credit supply: Measuring the Impact of Prudential Standards," Occasional Papers 36, Financial Services Authority.

[13] Francis, W.B., and M. Osborne (2012), "Capital requirements and bank behaviour in the UK: are there lessons for international capital standards?", Journal of Banking and Finance, 36, 803-816.

[14] Gambacorta, L., and P. E. Mistrulli (2013),"Bank Heterogeneity and Interest Rate Setting: What Lessons have we Learned since Lehman Brothers?" (with P.E. Mistrulli), Journal of Money Credit and Banking, forthcoming

[15] Hancock, D., and J. A. Wilcox (1993), "Has there been a "capital crunch" in banking? The effects on real estate lending of real estate conditions and bank capital shortfalls". Journal of Housing Economics 3 (1), 31-50.

[16] Hancock, D., and J. A. Wilcox (1994), "Bank capital and the credit crunch: The roles of risk-weighted and unweighted capital regulations". American Real Estate and Urban Economics Association Journal 22 (1), 59-94.

[17] Hanson, S.G., A.K. Kashyap and J.C. Stein (2010), "An Analysis of the Impact of "Substantially Heightened" Capital Requirements on Large Financial Institutions", mimeo.

[18] Hanson, S.G., A.K. Kashyap and J.C. Stein (2011), "A Macroprudential Approach to Financial Regulation," Journal of Economic Perspectives, vol. 25(1), pages 3-28, Winter.

[19] Houston, J., C. James, and D. Marcus (1997), "Capital Market Frictions and the Role of Internal Capital Markets in Banking". Journal of Financial Economics 46: 135-64.

[20] Institute of International Finance (IIF, 2010) "Interim Report on the Cumulative Impact on the Global Economy of Proposed Changes in the Banking Regulatory Framework."

[21] Judson, R.A. and A.L. Owen (1999), "Estimating dynamic panel data models: a guide for macroeconomists," Economics Letters, vol. 65(1), pages 9-15, October.

[22] Khwaja, A., and A. Mian (2008), "Tracing the impact of bank liquidity shocks." American Economic Review, 98 (4), 1413-42. 
[23] Maurin, Laurent \& Toivanen, Mervi, 2012. "Risk, capital buffer and bank lending: a granular approach to the adjustment of euro area banks," Working Paper Series 1499, European Central Bank.

[24] Modigliani, F., and M. H. Miller (1958), The Cost of Capital, Corporation Finance, and the Theory of Investment, American Economic Review 48, 162 - 197.

[25] Myers, S.C. (1977), "Determinants of corporate borrowing," Journal of Financial Economics, Elsevier, vol. 5(2), pages 147-175, November.

[26] Myers, S.C. and N.S. Majluf (1984), "Corporate Financing and Investment Decisions When Firms Have Information that Investors Do Not Have," NBER Working Papers 1396.

[27] Paravisini, D. (2008), "Local Bank Financial Constraints and Firm Access to External Finance", The Journal of Finance, 63(5), pp. 2161-2193.

[28] Peek, J and Rosengren, E S (1997), "The international transmission of financial shocks: the case of Japan", American Economic Review, 87:4, pp. 495-505.

[29] Puri, M., J. Rocholl and S. Steffen (2009), "Global Retail Lending in the Aftermath of the US Financial Crisis: Distinguishing between Supply and Demand Effects", Journal of Financial Economics, 100, pages 556-578. 